\title{
Relationship between Superoxide Dismutase Manganese Gene Polymorphism and Eye Tumors
}

\author{
Rodiah Rahmawaty Lubis ${ }^{1 *}$, Cut Adeya Adella ${ }^{2}$, Lokot Donna Lubis ${ }^{3}$ \\ ${ }^{1}$ Department of Ophthalmology, Faculty of Medicine, Universitas Sumatera Utara, Sumatera Utara, Indonesia; ${ }^{2}$ Department \\ of Obstetrics and Gynecology, Faculty of Medicine, Universitas Sumatera Utara, Sumatera Utara, Indonesia; ${ }^{3}$ Department of \\ Histology, Faculty of Medicine, Universitas Sumatera Utara, Sumatera Utara, Indonesia
}

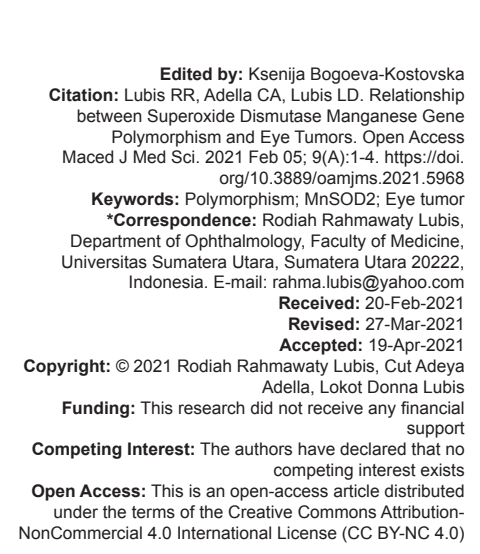

\section{Introduction}

Oxidative stress is believed to play an important role in tumor formation. Previous in vitro, animal, and human studies have shown that oxygen-free radicals play an important role in several pathological conditions, including cardiovascular disease, neurological disorders, aging, and cancer [1]. Free radicals or reactive oxygen species (ROS) are atoms or molecules with unpaired electrons in the outermost part of their orbit, so they become unstable and highly reactive components and try to attract stable electrons from molecules so that they can damage cell structures such as carbohydrates, nucleic acids, lipids, proteins, and change the function of these cells [2]. ROS is produced in the body of living things as a result of metabolism, as well as from environmental factors such as air pollutants or cigarette smoke. (Birben et al., 2012)

Several enzymes are known to function to prevent or reduce damage caused by ROS,
Including Superoxide Dismutase (SOD), Glutathione Peroxidase, Catalase (CAT), Nitric Oxide Synthase, and Para Oxonase [3]. SOD is an intracellular antioxidant. SOD plays an important role in protecting cells against oxidant disorders, oxidative stress, which can cause several diseases and degenerative processes such as aging and carcinogenesis. The level of natural SOD in the body decreases with age, making a person more susceptible to oxidative stressrelated illnesses [4]. Based on the metal cofactors found at the active site, SOD can be classified into three different groups, namely: Copper-Zinc-SOD (Cu, Zn-SOD), Manganese SOD (Mn-SOD), and EcSOD [5]. The previous studies have shown that most cancer cells have lower levels of MnSOD than normal cells. Apart from suppressing tumorigenesis, SOD has also been shown to have the potential to provide differential protection for normal cells or tissues against the side effects caused by anticancer therapy. This study aims to determine the relationship of SOD2 polymorphisms to the incidence of orbital tumors. 


\section{Methods}

This study is an analytical observational study with a cross-sectional data collection method for all patient aged $>18$ years who have been diagnosed with intra- and extra-ocular orbital tumors or adnexal tumors who have undergone supporting examinations of fineneedle aspiration biopsy (FNAB) conducted by an anatomic pathology specialist. Patients with eye infections, a history of trauma, a history of previous surgical removal of tumors in the other eye as well as patient with a history of recurrent socket surgery were excluded from the study. All patient who met the criteria for the study sample were recorded for their identity/demographic data, followed by FNAB examination by an anatomic pathology specialist, followed by an amplification examination of the manganese SOD gene and an Restriction Fragment Length Polymorphism (RFLP) examination after obtaining written informed consent from the research subject and approval from the Research Ethics Commission Health of FK USU and with permission from Hospital University of Sumatera Utara and H. Adam Malik General Hospital Medan. The examination was carried out at the Integrated Laboratory of FK USU, Medan.

Examination of manganese SOD gene amplification using a blood sample taken from the median cubital vein as much as $5 \mathrm{ml}$ and put in an EDTA tube centrifuged at $3000 \mathrm{rpm}$ for $10 \mathrm{~min}$. Then proceed with DNA extraction using a DNA genomic Extraction kit (Promega, USA). Manganese SOD2 gene amplification examination was carried out using DNA templates stored in a refrigerator at $-80^{\circ} \mathrm{C}$ through the Polymerase Chain Reaction (PCR) method against the master mix mixture $(12.5 \mu \mathrm{l})$, each primer (1 $\mu \mathrm{l}$ for each primer), DNA template $(2 \mu \mathrm{l})$, and nuclear-free water $(8.5 \mu \mathrm{l})$ (Promega, USA) using 5'-CAG CCC AGC CTG CGG AGA CGG-3 ' forward primer and 5'-CTT GGC reverse primer CAA CGC CTC CTG GTA CTT-3 '. The amplification process begins with initial denaturation of DNA at $95^{\circ} \mathrm{C}$ for $5 \mathrm{~min}$, followed by $9{ }^{\circ} \mathrm{C}$ for $45 \mathrm{~s}$ (melting), $54^{\circ} \mathrm{C}$ for $30 \mathrm{~s}$ (annealing), and $72^{\circ} \mathrm{C}$ for $30 \mathrm{~s}$, followed by electrophoresis using agarose $4 \%$, and staining using ethidium bromide. The examination of the RFLP of the manganese SOD2 gene (ala16 Val) was carried out by making a PCR solution mixture of 10 $\mu$ l digested by the RFLP method using $0.2 \mu$ of restriction enzyme BsaW1 endonuclease at temperature $60^{\circ} \mathrm{C}$ for $10 \mathrm{~min}$, and the product was analyzed using $4 \%$ agarose gel electrophoresis. RFLP results were read after staining with ethidium bromide.

\section{Results and Discussion}

This study consisted of 30 patients who had been diagnosed with orbital tumors and 30 healthy patients as controls who underwent blood tests and performed DNA examinations. Table 1 shows the basic characteristics of the research subjects.

Table 1: Characteristics of research subjects

\begin{tabular}{|c|c|c|c|}
\hline \multirow[t]{2}{*}{ No. } & \multirow[t]{2}{*}{ Characteristics } & Case & Control \\
\hline & & \multicolumn{2}{|l|}{$\mathrm{n}$} \\
\hline \multirow[t]{3}{*}{1} & Gender & & \\
\hline & Man & 17 & 20 \\
\hline & Woman & 13 & 10 \\
\hline 2 & Average age, years & $61.8(20-78)$ & $38.8(22-48)$ \\
\hline \multirow[t]{3}{*}{3} & Profession & & \\
\hline & Outdoor & 20 & 12 \\
\hline & Indoor & 10 & 18 \\
\hline \multirow[t]{4}{*}{4} & Laterality & & \\
\hline & Right eye & 13 & \\
\hline & Left eye & 17 & \\
\hline & Right and left eye & 0 & \\
\hline \multirow[t]{4}{*}{5} & Visual acuity & & \\
\hline & $6 / 60$ & 14 & 30 \\
\hline & $1 / 60-5 / 60$ & 12 & 0 \\
\hline & $1 / 300$ & 4 & 0 \\
\hline \multirow[t]{3}{*}{6} & Tumor & & \\
\hline & Benign & 9 & \\
\hline & Malignant/malignant & 21 & \\
\hline \multirow[t]{3}{*}{7} & Location of the tumor in the eye & & \\
\hline & Adnexa and eyelids & 18 & \\
\hline & Orbita & 12 & \\
\hline \multirow[t]{4}{*}{8} & Location of origin of the tumor & & \\
\hline & Primary lesions & 29 & \\
\hline & Secondary lesions & 1 & \\
\hline & Metastatic tumor & & \\
\hline
\end{tabular}

Most of the patients with orbital tumors in this study were male, as many as 17 patients with the mean age of the patient with orbital tumors was 61.8 years. In the control group, the male to female ratio was 2: 1 , with a mean age of 38.8 years. Most of the orbital tumor patients had a history of working outdoors (outdoors), while in the control group, most had a history of working indoors (indoors). In terms of laterality, the left eye had more orbital tumors than the right eye (17 patients vs. 13 patients). There was no bilateral orbital tumor patient (right and left eye). Only four patients with orbital tumors had visual acuity $\leq 1$ / 300 , while all control samples had fairly good visual acuity, that is, $\leq 6 / 60$, where after further examination, all controls could be corrected with glasses to become better visual acuity, that is, $6 / 6$. Of the 30 samples of orbital tumors, it was found that the most malignant types were found, that is, 21 patients with the most common location of the eye with tumors were adnexal and eyelid, as many as 18 patients, and as many as 29 patients were tumors with primary lesions in the eye.

Table 2 shows that most eye tumors were benign as many as 16 patients, and the most common were papillomas and palpebral cysts. Whereas malignant tumors are found in as many as 14 patients, the most common case is squamous cell carcinoma and sebaceous gland carcinoma.

Mann-Whitney test showed an association between MnSOD gene polymorphisms and the incidence of orbital tumors $(P<0.001)$. From Table 3 we found that in the group of orbital tumors, the genotype VV was more than 18 patients (60\%), while in the control group, the genotype $\mathrm{VV}$ was found to be at least 3 patients (10\%). 
Table 2: Characteristics of histopathological features of orbital tumor cases

\begin{tabular}{lll}
\hline Histopathological features of orbital tumors & Amount (n) & Frequency (\%) \\
Benign tumor & 16 & 100 \\
Papilloma & 3 & 18.75 \\
Palpebral cyst & 3 & 18.75 \\
Meningioma & 2 & 12.5 \\
Lipoma & 2 & 12.5 \\
Nevus & 2 & 12.5 \\
Actinic keratosis & 1 & 6.25 \\
Glioma & 1 & 6.25 \\
Epidermal cyst & 1 & 6.25 \\
Pyogenic granuloma & 1 & 6.25 \\
Malignant tumor & 14 & 100 \\
Squamous cell ca & 4 & 28.57 \\
Sebaceous gland ca & 4 & 28.57 \\
Basal cell ca & 3 & 21.42 \\
Adenoid cystic ca & 1 & 7,14 \\
Choroid melanoma & 1 & 7,14 \\
Rhabdomyosarcoma & 1 & 7,14 \\
\hline
\end{tabular}

Table 3: Relationship between MnSOD gene polymorphisms and orbital tumors

\begin{tabular}{llll}
\hline Characteristics & Orbital tumor $\mathrm{n}=30$ & Control $\mathrm{n}=30$ & $\mathrm{p}$ \\
\hline Genotype & $\mathrm{n}(\%)$ & $\mathrm{n}(\%)$ & \\
$\mathrm{AA}$ & 0 & $15(50)$ & \\
$\mathrm{AV}$ & $12(40)$ & $12(40)$ & $<0.001^{*}$ \\
$\mathrm{VV}$ & $18(60)$ & $3(10)$ & \\
\hline${ }^{*}$ Mann-Whitney & & &
\end{tabular}

The Mann-Whitney test (Table 4) showed an association of MnSOD gene polymorphisms with the incidence of orbital tumors with female sex $(P<0.001)$, but there was no correlation between MnSOD gene polymorphisms and the incidence of orbital tumors with male gender $(P=0.114)$.

Table 4: Relationship between MnSOD gene polymorphisms and orbital tumors based on sex

\begin{tabular}{llll}
\hline Genotype & Orbital tumor $\mathrm{n}=30$ & Control $\mathrm{n}=30$ & $\mathrm{p}$ \\
\hline Man & & & \\
AA & 0 & 4 & $0.114^{*}$ \\
AV & 5 & 5 & \\
VV & 4 & 3 & \\
Woman & & & $<0.001^{*}$ \\
AA & 0 & 11 & \\
AV & 7 & 7 & \\
VV & 14 & 0 &
\end{tabular}

From this study, it can be seen that as many as 30 patients with tumors in the eye who met the inclusion criteria, the largest gender was male, this is in line with previous studies reported by Ardjaja et al. [6] The incidence of orbital tumors is more common in outdoor workers than in indoor workers. This is in line with research reported by Orkić et al., where outdoor workers were more likely to suffer from nonmelanocytic tumors of the eyelids when compared to indoor workers [7]. This study showed that the left eye had more tumors than the right eye, and the most visual acuity was $6 / 60$. Malignant tumors in the eye are more common, with adnexal and eyelid locations the most common. Almost all of the location of origin of the tumor is in the eye; as many as, 29 patients with benign tumors are the most common papilloma and a dermoid cyst on the eyelid, while the malignant tumor most often found in squamous cell carcinoma and sebaceous gland carcinoma.

There were significant genotypic differences in the MnSOD gene in the orbital tumor group and the control group $(P<0.001)$. In the orbital tumor group, the most genotypes of the MnSOD gene were VV allele as much as $60 \%$ and $\mathrm{AV}$ allele as much as $40 \%$. Whereas in the control group, the most common MnSOD gene genotypes were the AA allele $(50 \%)$, followed by the AV allele $(40 \%)$ and the VV allele $(10 \%)$. To date, the authors have not found studies linking the MnSOD gene polymorphism to the incidence of eye tumors. However, Wang's 2018 study showed that MnSOD gene polymorphisms were associated with cancer as a whole (breast, prostate, lung, bladder, pancreatic cancer, colorectal, ovarium, hepatocellular carcinoma, and nonHodgkin's lymphoma) and subgroup analysis found an association between MnSOD gene polymorphisms and prostate cancer and no association with breast cancer. However, previous metanalytic studies by Kang in 2015 and Bang in 2008 showed that there was no relationship between MnSOD gene polymorphisms and overall cancer incidence [8], [9], [10].

\section{Conclusion}

Based on the objective of this study we found the result that there was a relationship between MnSOD gene polymorphisms and the incidence of orbital tumors.

\section{References}

1. Hussain SP, Hofseth LJ, Harris CC. Radical causes of cancer. Nat Rev Cancer. 2003;3(4):276-85.

PMid:12671666

2. Birben E, Sahiner UM, Sackesen C, Erzurum S, Kalayci O Oxidative stress and antioxidant defense review article. World Allergy Organ J. 2012;5(1):9-19. https://doi.org/10.1097/ wox.0b013e3182439613

PMid:23268465

3. Rajaraman P, Hutchinson A, Rothman N, Black PM, Fine HA, Loeffler JS, et al. Oxidative response gene polymorphisms and risk of adult brain tumors. Neuro Oncol. 2008;10(5):709-15. https://doi.org/10.1215 / 15228517-2008-037

PMid: 18682580

4. Tutik W, Made A. Deteksi Secara Imunohistokimia Antioksidan Superoxide Dismutase (Sod) Pada Jaringan Tikus Hiperkolesterolemia, Bandung; 2004.

5. Younus $\mathrm{H}$. Therapeutic potentials of superoxide dismutase. Int $J$ Health Sci (Qassim). 2018;12(3):88-93.

PMid:29896077

6. Ardjaja Y. Characteristic of ocular surface squamous neoplasia in Sanglah General hospital Denpasar 2013-2015. Medicina. 2017;48(3):157-162. https://doi.org/10.15562/medicina.v48i3.144

7. Želmir O, Puntarić D, Vidosavljević D. Climatic Factors and epidemiologic characteristics of head and neck skin malignancies in Osijek Baranja County, Croatia. Cent Eur J Public Health. 2015;23(4):275-85. https://doi.org/10.21101/ cejph.a4075

PMid:26841139 
8. Wang P, Zhu Y, Xi S, Li S, Zhang Y. Association between MnSOD Val16Ala polymorphism and cancer risk: Evidence from 33,098 cases and 37,831 controls. Dis Markers. 2018;2018:3061974. https://doi.org/10.1155 / 2018/3061974 PMid:30245752

9. Kang SW. Superoxide dismutase 2 gene and cancer risk: Evidence from an updated meta-analysis. Int $\mathrm{J}$ Clin Exp Med. 2015;8(9):14647-55.
PMid:26628947

10. Bag A, Bag N. Target sequence polymorphism of human manganese superoxide dismutase gene and its association with cancer risk: A review. Cancer Epidemiol Biomarkers Prev. 2008;17(12):3298-305. https://doi.org/10.1158 / 1055-9965. epi-08-0235

PMid:19064542 